\title{
Chinese Listed Companies Preference to Equity Fund:
}

\section{Non-Systematic Factors}

\author{
Hao Zeng (Corresponding author) \\ School of Management, South-Central University for Nationalities \\ Wuhan 430074, China \\ E-mail: zenghao1011@163.com \\ Junxia Xu \\ Auditing Department, Wuhan Tongji Hospital \\ Wuhan 430030, China
}

\begin{abstract}
This article concentrates on the listed companies' financing activities in China, analyses the reasons that why the listed companies prefer to equity fund from the aspect of non-systematic factors by using western financing theories, such as financing cost, types and qualities of the enterprises' assets, profitability, industry factors, shareholding structure factors, level of financial management and society culture, and concludes that the preference to equity fund is a reasonable choice to the listed companies according to Chinese financing environment. At last, there are some concise suggestions be given to rectify the companies' preference to equity fund.
\end{abstract}

Keywords: Equity fund, Non-systematic factors, Financial cost

\section{Introduction}

The listed companies in China prefer to equity fund, According to the statistic data showed in $<$ China Securities Journal $>$, the amount of the listed companies finance in capital market account to 95.87 billions in 1997, among which equity fund take the proportion of $72.5 \%$, and the proportion is $72.6 \%$ in 1998 and $72.3 \%$ in 1999 , on the other hand, the proportion of debt fund to total fund is respective $17.8 \%, 24.9 \%$ and $25.1 \%$ in those three years. The proportion of equity fund to total fund is lower in the developed capital market than that in China. Take US for example, when American enterprises need to fund in the capital market, they prefer to debt fund than equity fund. The statistic data shows that, from 1970 to 1985, the American enterprises' debt fund financed occupied the $91.7 \%$ proportion of outside financing, more than equity fund. Yan Dawu etc. found that, approximately $3 / 4$ of the listed companies preferred to equity fund in China. Many researchers agree upon that the listed companies' outside financing following this order: first one is equity fund, second one is convertible bond, third one is short-term liabilities, last one is long-term liabilities.

Many researchers usually analyze our national listed companies' preference to equity fund with the systematic factors arising in the reform of our national economy. They thought that it just because of those systematic facts that made the listed companies' financial activities betray to western classical financing theory. For example, the "picking order" theory claims that when enterprise need fund, they should turn to inside fund (depreciation and retained earnings) first, and then debt fund, and the last choice is equity fund. In this article, the author thinks that it is because of the specific financial environment that activates the enterprises' such preference, and try to interpret the reasons of that preference to equity fund by combination of non-systematic factors and western financial theories.

\section{Financingl cost of the listed company and preference to equity fund}

According to western financing theories, capital cost of equity fund is more than capital cost of debt fund, thus the enterprise should choose debt fund first, then is the turn to equity fund when it fund outside. We should understand that this conception of "capital cost" is taken into account by investors, it is somewhat opportunity cost of the investors, can also be called expected returns. It contains of risk-free rate of returns and risk rate of returns arising from the investors' risk investment. It is different with financing cost in essence. Financing cost is the cost arising from enterprises' financing activities and using fund, we can call it fund cost. If capital market is efficient, capital cost should equal to 
fund cost, that is to say, what investors gain in capital market should equal to what fund raisers pay, or the transfer of fund is inevitable. But in an inefficient capital market, the price of stock will be different from its value because of investors' action of speculation; they only chase capital gain and don't want to hold the stocks in a long time and receive dividends. Thus the listed companies can gain fund with its fund cost being lower than capital cost.

But in our national capital market, capital cost of equity fund is very low; it is because of the following factors: first, the high P/E Ratio (Price Earning Ratio) of new issued shares. According to calculation, average P/E Ratio of Chinese listed companies' shares is between 30 and 40 , it also is maintained at 20 although drops somewhat recently. But the normal P/E Ratio should be under 20 according to experience. We can observe the P/E was only 13.2 from 1874 to 1988 in US, and only 10 in Hong Kong. High P/E Ratio means high share issue price, then the capital cost of equity fund drops even given the same level of dividend. Second, low dividend policy in the listed companies, capital cost of equity fund decided by dividend pay-out ratio and price of per share. In China, many listed companies pay little or even no dividends to their shareholders. According to statistic data, there were 488 listed companies paid no dividend to their shareholders in 1998, 58.44 percents of all listed companies, there were 590, 59.83 percents in 1999, even 2000 in which China Securities Regulatory Commission issue new files to rule dividend policy of companies, there were only 699 companies which pay dividends, 18.47 percents more than that in 1999, but dividend payout ratio deduce $22 \%$. Thus capital cost of equity is very low. Third, there is no rigidity on equity fund, if the listed companies choose equity fund, they can use the fund forever and has no obligation to return this fund. Most of listed companies is controlled by Government in China, taking financing risk into account, the major stockholders prefers to equity fund. The management also prefer equity fund because its lower fund cost and needn't to be paid off, then their position will be more stable than financing in equity fund.

We can conclude from the above analysis that cost of equity fund is lower than cost of debt fund in Chinese listed companies and the listed companies prefer to such low-cost fund.

\section{Types and qualities of assets in listed companies and preference to equity fund}

Static Trade-off Theory tells us, the value of enterprise with financial leverage is decided by the value of self-owned capital; value arising from tax benefit, cost of financial embarrassment and agency cost. Cost of financial embarrassment and agency cost are negative correlative to the types and qualities of companies' assets, if the enterprise has more intangible assets, more assets with lower quality, it will has lower liquidity and its assets have lower mortgage value. When this kind of enterprise faces to great financial risk, it will have no way to solve its questions by selling its assets. Furthermore, because care for the ability of turning into cash of the mortgage assets, the creditors will high the level of rate and lay additional items in financial contract to rule the debtor's action, all of those will enhance the agency cost and deduce the companies' value. Qualcomm is supplier of wireless data and communication service in America, it is the inventor and user of CDMA, it also occupies the technology of HDR. The market value of its share is 1120 billions dollars at the end of March, 2000, but the quantities of long-term liabilities is zero. Why? Some reasons may be that there are some competitors in the market who own analogous technologies and the management of Qualcomm Company takes conservative attitude in financing activities. But the most important factor may be Qualcomm Company's owning a mass of intangible assets which will have lower convertibility and the company's value will decline when it has no enough money to pay for its debt.

Many listed companies in China is transformed from the national enterprises. In the transformation, these listed companies take over the high-quality assets of the national enterprises, but with the development of economy, some projects can not coincide with the market demand and the values of relative assets decline. On the other hand, there are many intangible assets in new high-tech companies. State-owned companies and high-tech companies are the most parts of the capital market. We can conclude that the qualities of listed companies' assets are very low. This point is supported by the index of $\mathrm{P} / \mathrm{B}$ (Price-to-Book value) which is usually thought as one of the most important indexes which can weigh the qualities of the listed companies' assets. According to statistic data coming from Shenzhen Securities Information Company, by the end of November 14, 2003, there were 412 companies whose P/B is less than 2, take the $30 \%$ proportions of total listed companies which issue A-share in China, among them, there were 150 companies whose $\mathrm{P} / \mathrm{B}$ is less than 1.53, and weighted average $\mathrm{P} / \mathrm{B}$ of the stock market is 2.42 . Lower qualities of assets means more cost may be brought out from debt fund and lower total value of the listed companies. Thus the listed companies prefer to equity fund when need outside financial support in China.

\section{Profitability and preference to equity fund}

Financial Leverage Theory tells us that a small change in company's profit may make great change in company's EPS (Earnings per share). Just like leverage, we can get an amplified action by use of it. Debt fund can supply us with this leverage, by use of debt fund, these companies which have high level of profitability will get higher level of EPS because debt fund produces more profit for shareholders than interest shareholder shall pay. On the contrary, these companies which have low level of profitability will get lower level of EPS by use of debt fund because debt fund can not produce enough profit for shareholder to fulfill the demand of paying off the interests. 
Edison International Company has steady amount of customers and many intangible assets, these supply it with high level of profitability and ability to gain debt fund, its debt account to $67.2 \%$ proportions of its total assets in 1999 .

Listed companies in developed countries or regions always have high level of profitability. Take US for example, there are many listed companies which have excellent performance in American capital market when do business, such as J.P Morgan, its EPS is \$11.16 per share in 1999. Besides it, GM, GE, Coca Cola, IBM, Intel, Microsoft, Dell etc. all always are profitable. In Hong Kong, most of those companies whose stock included in Hang Seng Index have the level of EPS more than $1 \mathrm{HKD}$, many are more than $2 \mathrm{HKD}$. Such as Cheung Kong (Holdings) Limited, its EPS is $7.66 \mathrm{HKD}$. But listed companies do not have such excellent performance in profitability in China inland. Their profitability is common low. Take the performance of 2000 for example, the weighted average EPS of total listed companies is only 0.20 Yuan per share, and the weighted average $\mathrm{P} / \mathrm{B}$ is 2.65 Yuan per share, 8.55 percents of these listed companies have negative profit. With low or no profit, the benefit can be gained from debt fund is very little; the listed companies can even suffer from the financial distress caused by debt fund. So with the consideration of shareholders' interest, the listed companies prefer to equity fund when need outside financial support in China.

\section{Industry factors and preference to equity fund}

China's industrial organization is during the course of intense changes, that is to say profit margin increase according to the scales of enterprises. Looked from the financing perspective, large enterprises have more convenient financing conditions and occupy financing advantages in the fierce competitive environment. These competitive advantages may include having more funds for research and development, market development for large enterprises. In this sense, the interaction of industrial organization and financing structures affect the choice of financing plan. In the competitive sectors, such as household electrical appliance industries, on the one hand, as competition intensifies, profit margins drop more and more low, and lower than the rate of debt fund, if using debt fund, it is probable to make the enterprise drop into financial difficulties, and income became instable, when facing to risk such as insufficient demand, change of consumer preferences, competition with similar products and technology risks brought by rapid product upgrading. On the other hand, the entry of multinational companies makes technological progress accelerate. The enterprises which want to remain competitive, need to increase investment in research and development, but Chinese Enterprises' investment in research and development are seriously inadequate. Therefore enterprises need to continue to invest and develop new products, upgrade products and manufacturing processes, increase manufacturing efficiency to reduce costs, gain more market share, and R\&D investment is in large quantities, the risk is great. In such a competitive environment, enterprises in these sectors in order to avoid falling into financial difficulties will inevitably reduce the amount of debt financing.

In an industry with intense competition and frequent price war, the current capital structure of enterprise will have an impact on the follow-up product market competition. High financial leverage has negative impact significantly on the financial ability to bear the investment capacity of enterprises and follow-up price war, making the company suffer disadvantages of operating strategy. Enterprises only with high operating efficiency can't be ensured to survive. These enterprises with high operational efficiency and adequate financial resources, that is, enterprises with low financial leverage, will have long-term survival. The current selection of equity financing help enterprises maintain the ability to re-investment when profitability and cash flow decline, go further, if competitors choose equity financing, enterprises choose debt financing may incited competitors to launch a price war to force enterprises to withdraw from the market.

But in monopoly industries, such as utilities, there is no product research and development, upgrading and marketing issues, the risk of revenue came mainly from insufficient demand, rather than competition. Product or service prices are relatively stable, with higher margins and stability, debt financing generally will not lead to financial difficulties. Therefore, these industries can use debt fund to support the development of enterprises.

To sum up, in different industrial structure and with different financial leverage, the differences of financing of listed companies is very significant. Sector is an important factor to determine the structure of corporate finance, industry factors or characteristics of industry factors can be a very good explanation of some Chinese listed companies' equity financing preferences actions.

\section{Shareholding structure factors and preference to equity fund}

Listed companies not only face to external financing environmental impacts, but also the structure of the companies shares. Shareholding structure of Chinese listed companies shows characteristics as followed: I. Ownership structure is fairly complex. In addition to the public shares, there are shares held with inland fund and foreign stocks, state-owned shares, legal person shares, and internal employee shares, transferred allotted shares, A shares, B shares, H shares And $\mathrm{N}$ shares, and other distinction. From 1995 to 2003, Chinese companies' outstanding shares of the total equity share almost have no change, even declined slightly. II. There are different prices, dividends, and rights of shares issued by same enterprise. III. The over-concentration of shares.

We use the quantity of shares of the three major shareholders who top the list of shareholders of the listed companies to 
measure the concentration of stock. We study the concentration of stock of these companies which issue new share publicly in the years from 1995 to 2003 and focus on the situation of Chinese listed companies over the same period. The results showed that: from 1995 to 2003, the company-Which once transferred or allotted shares-whose top three shareholders' shareholding ratio are generally higher than the average level of all the listed companies, and most of these company's top three shareholders holding 40 percent or higher percent of companies' shares. In some years, the maximum number even is more than 90 percent, indicating that the company with the implementation of transferred and allotted shares have relatively high concentration rate of shares and major shareholders have absolute control over it. In short, transferring allotting shares and the issuance of additional shares have a certain relevance to the company's concentration of ownership structure, the company's financing policy is largely controlled by the major shareholders.

Chinese listed companies' special shareholding structure effects its financing action. Because stockholders of the state-owned shares, legal person shares, social and outstanding shares, foreign share have a different objective function, their modes of financing preferences vary, and their preference affect the financing structure of listed companies. Controlling shareholders which hold state-owned shares account for the status of enterprises and carry out financing decisions in accordance with its own objective function. When the objective function conflict with the other shareholders benefit, they often damage the interests of other shareholders by use of the status of controlling. As the first major shareholders of the companies, government has multiple objectives, not always market-oriented, it prefers to use safe fund such as equity fund to maintain the value of state-owned assets, thus resulting in listed company's preference to equity financing. Debt financing bring business with greater pressure to pay off the par value and interests. Therefore, the state-owned company showing a more offensive attitude to debt fund, again because of Chinese state-controlled listed companies have the absolute status in all listed companies, listed companies' preference to equity fund is a reasonable phenomenon.

\section{Level of financial management skill, society culture and preference to equity fund}

Low level of financial management skill of listed companies is one of the most important reasons why they prefer to equity fund. Because of special development course, financial management is not paid enough attention and its level is very slow. Many enterprises have not enough retained earnings to support following investments and have to turn to outside financial support. Moreover, many financial managers of listed companies concentrate on reflection and control of enterprises' economic activities and finance fund to fulfill the enterprises' need of money, thus it is unavoidable that in many listed companies there are no efficient financial management and no rational choice of suitable financing methods or financing instruments.

On the other hand, there is such an idea in Chinese traditional culture that is called "Golden Means". According to this idea, the enterprise should not have much debt fund, because less debt fund means more stable financial position. It is a conservative thought, but people used to take it for granted who live in Chinese traditional culture. Thus many managers take conservative actions in their financial policies and prefer to equity fund which doesn't need to be paid for. Shown as Lu Zhengfei's research data, listed companies prefer to short-term liabilities than long-term liabilities in China.

\section{Conclusion}

There are many systematic reasons to interpret why Chinese listed companies prefer to equity fund, but it is not correct to ignore non-systematic factors which influence the listed companies' action potentially. In above analysis, we discuss financial cost, types and qualities of assets, profitability, industry factors, shareholding structure, level of financial management and society culture, all of those are non-systematic factors which lead to listed companies' preference to equity fund. We shall recognize that it is not a reasonable phenomenon. Listed companies will lose much investment chance if they depend mostly on equity fund because there are many strict terms and rules. Moreover listed companies' such irrational preference will make the use of economy resource inefficiently because these profitable listed companies may finance fund more than they need.

To rectify this irrational preference to equity fund, we shall build up a perfect capital market, in which all participators are rational and they should pay reasonable corresponding cost for each financial instrument they choose. Moreover the managers in listed companies shall improve their financial skills and make use of modern western financial theories in financial decisions. At last, we should rectify the shareholding structure of state-owned listed companies, and make those companies more profitable.

\section{References}

Barton et al. (2004). Investor Protection under Unregulated Financial Reporting. Journal of Accounting and Economics. Jensen M C, \& W H Meckling. (1976). Theory of the Firm: Managerial Behavior, Agency Costs and Ownership Structure. Journal of Financial Economics.

Johnson et al. (2000). Corporate Governance in the Asian Financial Crisis. Journal of Financial Economics. 
La Porta et al. (1998). Law and Finance. Journal of Political Economy.

La Porta et al. (2000). Investor Protection and Corporate Governance. Journal of Financial Economics.

Leuzet al. (2003). Investor Protection and Earnings Management: An International Comparison. Journal of Financial Economics.

Lu, Zhengfei, \& Gao, Qiang. (2003). Research on Chinese Listed Companies' Financial Action-Bases on questionnaire. Accounting Research, (10) (In Chinese).

Modigliani F, \& M H Miller. (1958). Corporate Income Taxes and the Cost of Capital: a Correction. American Economic Review.

Myers \& Majluf. (1984). Corporate Finance and Investment Decisions When Firms Have Information that Investors do not Have. Journal of Financial Economics.

Myers, Stewart C. (1984). The Capital Structure Puzzle. Journal of Finance.

Myers, S. C. (2003). Financing of Corporations. Handbook of the Economics of Finance: Corporate Finance.

Shleifer \& Vishny. (1994). Large Shareholders and Corporate Control. The Journal of Political Economy, 461-488.

Song, Lin. (2003). Analysis of Capital Cost and Financial Cost and Its Influence on Listed Companies' Preference to Equity Fund. Finance, (3) (In Chinese)

Stephen. A. Ross, Randolph. W. Westerfield, \& Teffrey. F. Jaffe. (2003). Corporate Finance. Beijing: China Machine Press. 